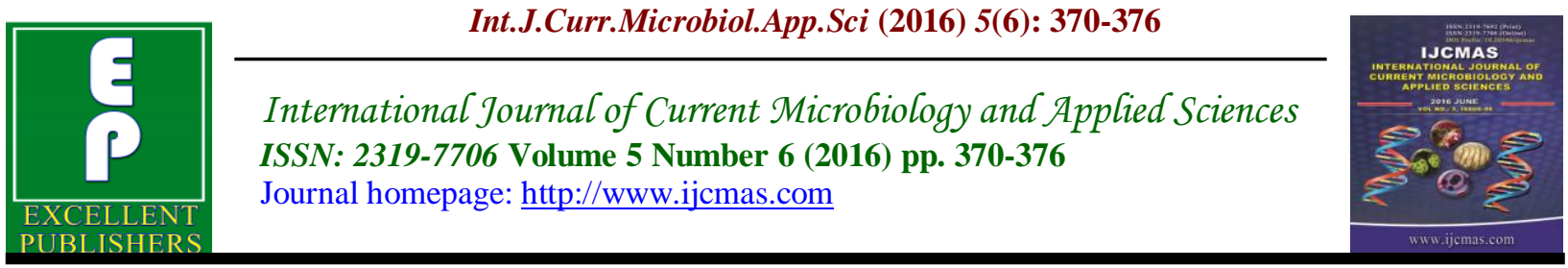

Original Research Article

http://dx.doi.org/10.20546/ijcmas.2016.506.042

\title{
Characterization and Cytotoxicity Assay of Pigment Producing Microbes
}

\author{
Kamla Malik $^{1 *}$, Jayanti Tokas ${ }^{2}$ and Ramesh Chand Anand ${ }^{1}$ \\ ${ }^{1}$ Department of Microbiology, College of Basic Science \& Humanities, \\ Chaudhary Charan Singh Haryana Agricultural University, Hisar 125004, Haryana, India \\ ${ }^{2}$ Department of Biochemistry, College of Basic Science \& Humanities, Chaudhary Charan Singh \\ Haryana Agricultural University, Hisar 125004, Haryana, India \\ *Corresponding author
}

\begin{tabular}{|c|c|}
\hline & A B S T R A C T \\
\hline $\begin{array}{l}\text { Ke y w o r d s } \\
\text { Pigment } \\
\text { producing } \\
\text { bacteria, } \\
\text { fungi, } \\
\text { extraction, } \\
\text { cytotoxicity. }\end{array}$ & $\begin{array}{l}\text { The pigment producing bacteria and fungi were isolated from soil, damping site, } \\
\text { compost, industrial effluent, spoiled fruits and vegetables. A total of fifteen } \\
\text { bacterial and nine fungal pigment-producing isolates were obtained and screened } \\
\text { on nutrient agar and potato dextrose medium, respectively. The pigments from } \\
\text { selected isolates were extracted by solvent extraction (acetone and methanol). The } \\
\text { antimicrobial activity of selected isolates was determined by disc agar diffusion } \\
\text { technique against standard isolates of Staphylococcus aureus, Klebsiella } \\
\text { pneumonia, Escherichia coli and Fusarium oxysporum. The cytotoxicity was } \\
\text { studied by using yeast toxicity test (YTT). Bacterial isolates BP-8 exhibited the }\end{array}$ \\
\hline Article Info & inhibitory effect against Saccharomyces cerevisiae and E.coli. The $\mathrm{R}_{\mathrm{f}}$ value of \\
\hline $\begin{array}{l}\text { Accepted: } \\
\text { 15 May } 2016 \\
\text { Available Online: } \\
\text { 10 June } 2016\end{array}$ & $\begin{array}{l}\text { was } 0.92 \text { by fungal isolate FP- } 6 \text { as determined by thin layer chromatography } \\
\text { (TLC). ). The bacterial isolates BP- } 2 \text { and BP- } 6 \text { were Gram+ve and BP- } 8 \text { was } \\
\text { Gram-ve. Out of these BP- } 6 \text { and BP- } 8 \text { were non spore former. These bacterial } \\
\text { isolates belonged to the genus Bacillus, Micrococcus and Serratia. The fungal } \\
\text { isolate was identified as Aspergillus sp. }\end{array}$ \\
\hline
\end{tabular}

\section{Introduction}

Now a day, there is an increasing demand for natural colors/pigments in various fields viz. food production, textile industries, paper production, cosmetic, pharmaceutical, printing and dye industries over synthetic colors by virtue of its carcinogenic and teratogenic nature (Unagul et al., 2005). Natural pigments not only have the capacity to increase the marketability of products but they also display advantageous biological activities as antioxidants and anticancer agents (Malik et al., 2012). These are easy to produce as compared to synthetic pigments and are economical as well (Tibor, 2007). Natural pigments have some limitations including solubility, sensitivity and short stability upon exposure to light, $\mathrm{pH}$ and high temperature. In this regard, a lot of attention is now being paid for synthesis of biocolors, also known as microbial pigments, by using the 
microorganisms (Cho et al., 2002). Thus, there is an ever growing interest in microbial pigments due to several reasons like their natural character, safe, fast growth, production being independent of seasons and geographical conditions. Moreover, the predictable yield and cost effectiveness can be further enhanced by growing on low-cost substrates. Various types of microbial sources like bacteria, yeasts, mold and algae are used for production of microbial pigments. Microbial pigments have numerous beneficial properties like anticancer, antiproliferative, immunosuppressive, antibiotic, biodegradability etc. Many microorganisms, including bacteria, fungi, yeast and mould etc. are employed for the industrial production of various pigments by using fermentation technology (Kumar et al., 2015).

Microbial pigments are of industrial interest because they are often more stable and soluble than those from plant or animal sources and can grow rapidly which can lead to high productivity and produce a product throughout the year (Jiang et al., 2005). Microorganisms are known to produce a variety of pigments like carotenoids, melanins, flavones, quinones, and more specifically monascins, violacein or indigo (Dufosse, 2007). In this way the pigments from microbial sources are a good alternative, therefore they are promising source of food colorants (Aberoumand, 2011; Ahmad et al., 2012). Food grade pigments such as $\beta$-carotene, arpink red, riboflavin lycopene and monascus pigments are used in food industries (Joshi et al., 2013). In pharmaceutical industry pigments like anthocyanin, prodigiosin and violacein are widely used to treat diseases. Several microbial pigments are also being used in textile industries (Kumar et al., 2015). In the present work, efforts have been made for screening, extraction, purification of pigments and identification of selected pigment producing bacterial and fungal isolates.

\section{Material and Methods}

\section{Isolation and Screening of Pigment Producing Bacteria and Fungi}

Samples were collected from soil, damping sites, compost, industrial effluent, spoiled fruits and vegetables. For isolation of pigment producing bacteria and fungi by using enrichment culture technique was used. The pigmented colonies were purified by streaking. The purified colonies of bacteria were then transferred on nutrient agar (NA) and fungal isolates on potato dextrose medium (PDA) slants. These cultures were maintained at $4{ }^{\circ} \mathrm{C}$.

\section{Extraction of Pigments}

The pigment from the selected bacterial and fungal isolates was extracted using different solvents viz. acetone, ethyl acetate, and methanol. The bacterial isolates were grown for 24- 48h in nutrient broth followed by centrifugation at $8000 \mathrm{rpm}$ for $20 \mathrm{~min}$. Both the supernatant and bacterial cell pellets were extracted using 95\% (v/v) methanol and $99 \%(\mathrm{v} / \mathrm{v})$ acetone in the ratio of 1: 5 until the pellet was colorless, i.e., complete pigment extraction was achieved. The fungal isolates were grown in potato dextrose broth. The culture broth was extracted using ethyl acetate and centrifuged at 10,000 rpm for $10 \mathrm{~min}$. The extract was scanned in the range of 400 to $600 \mathrm{~nm}$ to find out the maximum absorption spectra by UV-visible spectrophotometer. Methanol was used as a blank.

\section{TLC Analysis of Pigments}

Qualitative analysis of pigments was carried out by Thin Layer Chromatography (TLC). 
TLC plates were prepared by applying silica Gel G slurry which was dried at $100^{\circ} \mathrm{C}$ for one hour. Thereafter, $20 \mu$ of samples were spotted on the baseline of the TLC plates at $1.0 \mathrm{~cm}$ interval and then allowed to dry at room temperature. The sample applied on TLC plates was placed in a presaturated TLC chamber containing mobile phase (benzene/ acetone in the ratio of $2: 1 \mathrm{v} / \mathrm{v}$ ). Then the plate was taken out and dried for few min. After 45 min., the TLC sheet was carefully removed and the Retention factor $(R f)$ value was calculated according to the following equation from the chromatogram.

$\mathrm{R} f=$ Distance travelled by the compound/ Distance travelled by the solvent front

\section{Cytotoxicity Assay}

Pigment producing bacteria and fungi were grown in nutrient and potato dextrose broth. Pigments were extracted in different solvents (methanol and acetone). The antimicrobial activity of pigments was tested by agar well diffusion technique against clinical isolates of Staphylococcus aureus, Escherichia coli, Klebsiella pneumonia and Fusarium oxysporum. Methanol was used as control. The plates were incubated at $30^{\circ} \mathrm{C}$ for $24 \mathrm{~h}$ after which activity was measured by the presence of zone of inhibition surrounding the well. The experiment was done in triplicates. The antibacterial activity was expressed as the mean diameter of zone inhibition $(\mathrm{mm})$.The yeast toxicity test (YTT) was also done using Saccharomyces cerevisiae.

\section{Identification of Selected Isolates}

The selected bacterial isolates were further identified on the basis of morphological and biochemical characteristics, as outlined in Bergey's manual of systematic bacteriology (Brenner et al., 2005).

\section{Result and Discussion}

\section{Screening and Selection of Pigment Producing Isolates}

Twenty five bacterial and fifteen fungal isolates were obtained from different samples viz. soil, dumping sites, compost, industrial effluent, spoiled fruits and vegetables on nutrient agar and potato dextrose medium, respectively. Out of these 15 bacterial and nine fungal isolates were found to produce pigments of different colors such as red, yellow, pink, white and light blue. Table 1 presents the colony characteristics of selected pigment producing isolates. Preliminary morphological observations revealed that the colonies were circular, raised, smooth, yellow, pink and red in color.

\section{Characterization of Pigment}

Pigment producing bacterial and fungal isolates were grown in nutrient and potato dextrose broth, respectively and by centrifuged. Bacterial pellets were extracted using methanol and acetone in the ratio of 1:5 (v/v) and fungal isolates in ethyl acetate. The pigment extract was then analyzed by scanning the absorbance in the wavelength region of 400-600 nm using UV-Vis spectrophotometer. The maximum absorbance of red pigment (BP-8) was obtained at $532 \mathrm{~nm}$; orange $(\mathrm{BP}-1)$ at $450 \mathrm{~nm}$, yellow (BP-6) at $468 \mathrm{~nm}$, pink (BP-5) at 540 $\mathrm{nm}$ and black (FP-6) at 300nm. Similar studies have been carried out in Serratia marcescens where the maximum absorbance of red pigment by it was found to be at $534.76 \mathrm{~nm}$ using UV-Vis analysis spectra (Ahmad et al., 2012; Song et al., 2012). The maximum extraction of an orange pigment from Salinicoccus sp. M KJ997975 was done by using acetone: methanol (5:5) (v/v) solvent. The extracted pigment showed 
maximum absorbance at $450 \mathrm{~nm}$ (Bhat and Marar 2015).

The TLC analysis of extracted pigment from the different bacterial isolates showed different $R_{f}$ values. The $R f$ value of pigment producing selected isolates $r$ The $R_{f}$ value for BP-1, BP-5, BP-6 and BP-8 were 0.91, $0.86,0.88$ and 0.87 , respectively (Table 2 ). However, it was 0.92 for fungal isolate FP6 . The $R_{f}$ value of the extracted red pigment from Serratia marcescens KH1R KM035849 has been reported to be in the range of 0.64-0.96 when determined by TLC method (Vora et al., 2014). The $\mathrm{R}_{\mathrm{f}}$ value of prodigiosin (red) pigment was 0.73 which is near to our results (Mohammed et al., 2012).

TLC analysis of extracted orange pigment from Salinicoccus sp. M KJ997975 showed $R_{f}$ value of 0.65 in hypophase which suggested the presence of xanthophylls.

Table.1 Colony characteristics of selected pigment producing isolates

\begin{tabular}{ll}
\hline Isolate No. & Colony characteristics \\
\hline Bacterial Isolates & Orange, raised, shiny and smooth \\
BP- 1 & Off White, irregular, flat \\
BP- 2 & white, flat, rough and irregular \\
BP-3 & Light blue, irregular and raised \\
BP- 4 & Pink, raised and irregular \\
BP- 5 & Yellow, raised and smooth \\
BP-6 & white, flat, irregular and rough \\
BP- 7 & Red, raised, smooth and round \\
BP- 8 & Light yellow, raised, round and smooth \\
BP- 9 & Pinkish white, flat, irregular and rough \\
BP 10 & yellow, raised, gummy, and smooth \\
BP-11 & Off White, raised, round and smooth \\
BP-12 & Dark yellow, raised and shiny \\
BP-13 & Colorless, flat, irregular and rough \\
BP-14 & Pale yellow, raised and round \\
BP-15 & \\
Fungal Isolates & Pinkish white, flat, irregular and rough \\
FP-1 & White and cottony \\
FP-2 & Blackish brown and powdery \\
FP-3 & Pinkish white, cottony and fuzzy edges, \\
FP-4 & Yellowish white \\
FP-5 & Black, powdery \\
FP-6 & Off White, puffy, thick \\
FP-7 & White, cottony and fuzzy edges \\
FP-8 & Brownish with White edges \\
FP-9 &
\end{tabular}


Table.2 Rf value of pigment producing selected isolates

\begin{tabular}{ll}
\hline Isolate No. & $\mathbf{R}_{\mathbf{f}}$ value \\
BP-1 & 0.91 \\
BP-5 & 0.86 \\
BP-6 & 0.88 \\
BP-8 & 0.87 \\
FP-6 & 0.92 \\
\hline
\end{tabular}

Table.3 Morphological and biochemical characteristics of pigment producing bacterial isolates

\begin{tabular}{|c|c|c|c|}
\hline Test & Bacterial Isolate & & \\
\hline \multicolumn{4}{|c|}{ Morphological characteristics } \\
\hline & BP-2 & BP-6 & BP-8 \\
\hline Pigment & Off- white & Yellow & Red \\
\hline Colony morphology & flat, Irregular & raised, circular & raised, circular \\
\hline Cell shape & rods & cocci & rods \\
\hline Gram reaction & + & + & - \\
\hline Spore formation & + & - & - \\
\hline $\begin{array}{l}\text { Optimum temperature } \\
\text { growth }\end{array}$ & $30^{\circ} \mathrm{C}$ & $30^{\circ} \mathrm{C}$ & $35^{\circ} \mathrm{C}$ \\
\hline \multicolumn{4}{|c|}{ Biochemical characteristics } \\
\hline Catalase test & + & + & - \\
\hline Voges-proskauer & - & - & + \\
\hline Urease & - & + & - \\
\hline $\mathrm{H}_{2} \mathrm{~S}$ production & - & - & - \\
\hline Glucose fermentation & AG & AG & AG \\
\hline Genus & Bacillus & Micrococcus & Serratia \\
\hline
\end{tabular}

AG- Acid and gas production

Cytotoxicity Assay of Purified Pigment From Bacteria and Fungi

Red pigment extracted from bacterial isolate (BP-8) showed clear inhibition zone against Staphylococcus aureus $(4 \mathrm{~mm})$, Escherichia coli $(5 \mathrm{~mm})$ and Saccharomyces cerevisiae $(8 \mathrm{~mm})$. The prodigiosin pigment showed antibacterial activity against Staphylococcus aureus (17.5 mm), Bacillus cereus $(10.5 \mathrm{~mm})$, Escherichia coli $(5 \mathrm{~mm})$ (Gulani et al., 2012).

The red pigment produced by $\mathrm{BP}-8$ isolate showed the inhibitory effect against E.coli,
Staphylococcus aureus and Saccharomyces cerevisiae. The red pigment extracted from Serratia marcescens KH1R KM035849 exhibited antibacterial activity against B.cerus, S.aureus and E.coli with inhibition zone $12 \mathrm{~mm}, 07 \mathrm{~mm}$ and $06 \mathrm{~mm}$, respectively (Vora et al., 2014).

\section{Identification of Selected Isolates}

The pigment producing bacterial isolates were characterized on the basis of morphology and biochemical test. Microbiological and biochemical 
characteristics of pigment producing bacterial isolates (Table 3). These bacterial isolates BP-2 and BP-6 were found to Gram+ve and BP-8 as Gram-ve. Out of Gram+ve bacterial isolates BP-2 was spore former whereas BP-6 was nonspore former. Moreover, BP-2 isolate was rod shaped and BP-6 as cocci. Both of them were catalase positive and negative for Voges-proskauer and hydrogen sulfide production. So for urease activity is concerned, it was absent in BP-2 but present in BP-6. The color of pigment of isolate BP-2 was off-white and yellow of BP-6. It may be said that BP-2 isolate belong to Bacillus and BP-6 to Micrococcus. Isolate BP-8 showed raised, circular red pigmented colonies. In addition to Gram-ve and nonspore formation, it showed positive for Voges-proskauer test. It probably may belong to Serratia. Two bacterial isolates (MJ-O and MJ-Y) obtained had been shown to produce pigments. One of the bacteria (MJ-O) produced orange coloured pigment and the other one (MJ-Y) produced yellow colored pigment. The morphological characteristics of these bacteria were Gram positive, cocci and nonmotile. Hence MJ-O was identified as $M$. nishinomiyaensis and MJ-Y as Micrococcus luteus, respectively (Bhat et al., 2013).

In conclusion, different pigments were produced by bacterial and fungal isolates. These pigments were extracted in methanol and acetone in the ratio of 1:5 (v/v). The maximum absorbance of red pigment (BP-8) was obtained at $532 \mathrm{~nm}$; orange $(\mathrm{BP}-1)$ at 450nm, yellow (BP-6) at $468 \mathrm{~nm}$, pink (BP5) at $540 \mathrm{~nm}$ and black (FP-6) at $300 \mathrm{~nm}$.

The $\mathrm{R}_{\mathrm{f}}$ values of pigments ranged from 0.86 to 0.92 . Red pigment produced by BP-8 isolate showed the inhibitory effect against E.coli, Staphylococcus aureus and Saccharomyces cerevisiae.
The results indicated that the purified pigment contains antimicrobial substances, and it possesses the ability to inhibit the growth of human pathogens. On the basis of morphological and cultural characteristics, the bacterial isolates were found to resemble to the genus Bacillus, Serratia and Micrococcus.

\section{Acknowledgments}

Authors are thankful to Chaudhary Charan Singh Haryana Agricultural University, Hisar for providing facilities and financial support for the completion of this research work.

\section{References}

Aberoumand, A. 2011. A Review article on edible pigments properties and sources as natural biocolorants in foodstuff and food industry. World J. Dairy and Food Sci., 6: 71-78.

Ahmad, A.S., Ahmad, W.Y.W., Zakaria, Z.K. 2012. Application of bacterial pigments as colorant: The Malaysian perspective. Springer Briefs in Molecular Science, New York Publishers, pp. 57-74.

Bhat, R., Marar, T. 2015. Media optimization, extraction and partial characterization of an orange pigment from Salinicoccus sp. MKJ 997975. Int. J. Life Sci. Biotechnol. Pharma. Res., 4: 85-89.

Bhat, S.V., Khan, S.S., Amin, T. 2013. Isolation and characterization of pigment producing bacteria from various foods for their possible use as biocolours. Int. J. Recent Scientific Res., 4(10): 1605-1609.

Brenner, D.J., Krieg, N.R., Staley, J.T., Garrity, G.M. 2005. Bergey's Manual of Systematic Bacteriology, SpringerVerlag, New York Publishers, pp. 408-420. 
Cho, YJ., Park, JP., Hwang, HJ., et al. 2002. Production of red pigment by submerged culture of Paecilomyces sinclairii. Lett. Appl. Microbiol., 3: 195- 202.

Dufosse, L. 2007. Microbial production of food grade pigments. Food Technol. Biotechnol., 44: 313-321.

Gulani, C., Bhattacharya, S., Arijit, D. 2012. Assessment of process parameters influencing the enhanced production of prodigiosin from Serratia marcescens and evaluation of its antimicrobial, antioxidant and dyeing potentials. Malaysian J. Microbiol., 8: 116-122.

Jiang, Y., Chen, F., Hyde, K. 2005. Production potential of water-soluble Monascus red pigment by a newly isolated Penicillium sp. J. Agri. Technol., 1: 113-126.

Joshi, V.K., Attri, D., Bala, A., Bhusan, S. 2013. Microbial pigments. Indian $J$. Biotechnol., 2: 362-369.

Kumar, A., Vishwakarma, H., Singh, J. 2015. Microbial pigments: Production and their applications in various industries. Int. J. Pharmacy, Chem. Biol. Sci., 5(1): 203-212.
Malik, K., Tokkas, J., Goyal, S. 2012. Microbial pigments: A review. Int. J. Microbial Res. Technol., 1(4): 361365.

Mohammed, H., Naseer, J., Aruna, K. 2012. Study on optimization of prodigiosin production by Serratia marcescens MSK1 Isolated from air. Int. J. Adv. Biol. Res., 2: 671-680.

Song, C., Makoto, S., Osamu, J. et al. 2000. High production of prodigiosin by Serratia marcescens grown on ethanol. Biotechnol. Lett., 22: 17611765.

Tibor, C. 2007. Liquid chromatography of natural pigments and synthetic dyes. $J$. Chromatography Library. 71: 11-19.

Unagul, P., Wongsa, P., Kittakoop, P., Intamas, S., Srikiti-Kulchai, P. 2005. Production of red pigments by the insects pathogenic fungus Cordyceps unilateralis BCC 1869. J. Industrial Microbiol. Biotechnol., 32: 135-140.

Vora, J.U., Jain, N.K., Modi, H.A. 2014. Extraction, characterization and application studies of red pigment of halophile Serratia marcescens KH1R KM035849 isolated from Kharaghoda soil. Int. J. Pure and Appl. Biosci., 2: 160-168.

\section{How to cite this article:}

Kamla Malik, Jayanti Tokas and Ramesh Chand Anand. 2016. Characterization and Cytotoxicity Assay of Pigment Producing Microbes. Int.J.Curr.Microbiol.App.Sci. 5(6): 370376. doi: http://dx.doi.org/10.20546/ijcmas.2016.506.042 